\title{
Influence Factors of Teachers' Pro-Industry Professionalization: Linear Structural Analysis
}

\author{
Chun-Mei Chou/ Professor \\ Institute of Vocational and Technological Education \\ National Yunlin University of Science \& Technology, \\ Yunlin, Taiwan \\ choucm@yuntech.edu.tw \\ Hsi-Chi Hsiao/ Chair Professor \\ Department of Business Administration, Cheng Shin \\ University, Kaohsiung, Taiwan

\section{Yu-Jen Tsen} \\ Center for General Education, TransWorld University
}

\author{
Chien-Hua Shen/ Professor \\ Department of Business Administration \\ Transworld Institute of Technology \\ Yunlin, Taiwan \\ shen17@ms51.hinet.net
}

\author{
Tsu-Chguan Shen \\ Sacred Hearts High School, Yunlin, \\ Taiwan
}

Kuan-Fu Shen

Chien Hsin University of Science and Technology

Department of Finance, Taoyuan, Taiwa

\author{
Hsiang-Li Shen \\ Chien Hsin University of Science and Technology \\ Secretariat Office, Taoyuan, Taiwan
}

Department of Marketing and Logistics and Management, National Penghu University of Science and Technology, Penghu, Taiwan
Jia- Ming Chen

Institute of Vocational and Technological Education, National Yunlin University of Science \& Technology, Yunlin, Taiwan

\begin{abstract}
The paper examines 322 teachers' pro-industry professionalization and its influencing factors to serve as a school reference. The results show that teachers' pro-industry professionalization and its influence pattern, teaching selfefficacy has a significant effect on industry experience, but does not have a significant effect on pro-industry professionalization. Industry experience has a significant effect on pro-industry professionalization. The influence pattern and empirical data of teaching self-efficacy and industry experience on pro-industry professionalization has a good fit. Based on test results, although the overall result is acceptable, the model consistency level is not entirely satisfactory, and its teaching self-efficacy has a relatively low explanatory power for pro-industry professionalization. The possible reasons and implication was discusses.
\end{abstract}

Keywords-Pro-industry professionalization; Industry experience; teaching self-efficacy

\section{INTRODUCTION}

Teachers strengthen the practical skills is important who choose materials and compose ability of the industry practice course [1]. In view of the practical needs, the technical vocational school curriculum content of the professional subjects is influenced by the industrial development trend. Teachers' professional competence and specialized learning mechanism of pro-industry teaching will be emphasized of self-efficacy and industry experience [2-3].

Research found teachers' human cognition in social context and private self-awareness has provided them with chances to learn professional competence and skills, which may be helpful for their future teachers' professionalization [4-5]. Some research conduct of teachers' pro-industry professionalization factor as follows:

(1) Outcome value: an action or result.

(2) Outcome expectancy: subjective judgment and the relevance action of the outcome.

(3) Self-efficacy expectancy: subjective judgment of organizing and performing individual action. Teachers face pro-industry teaching professional to explore professional practice and adjustment process [5-7]. 
Teachers' pro-industry teaching specialization was conducted in the process of cognitive, not only to participate in the common industry-oriented curriculum, but also to practice quite personal characteristics. The process is cognitive adjustment that to use knowledge and main contributions of this study and to set up the teaching practice [8-9]. It is important to understand industry views of vocational education in the human cultivation and industry connotation.

\section{PURPOSES}

The paper, Analysis of factors in teachers perceived teaching self-efficacy and pro-industry professionalization, using industry experience as a mediator variable. The purposes of this study are to address the 2 following issues.

- There is no significant correlation between teachers' teaching self-efficacy, industry experience and proindustry professionalization.

- Influence models of teachers' teaching self-efficacy, industry experience, and pro-industry professionalization fit the data collected by this study

\section{METHODOLOGY}

\section{A. Subjects}

This study treats teachers from technical higher school as the population, and adopts random sampling and cluster sampling for survey. A total of 322 valid samples were collected.

\section{B. Measures}

A 41-item survey questionnaire was developed to measure participants' teaching self-efficacy, industry experience, and pro-industry professionalization. The research tool is a 'Questionnaire of Factors Which Influence Teachers' Proindustry professionalization.' The questionnaire includes teaching self-efficacy scale, industry experience scale and proindustry professionalization scale [10-12]. The scales' factors, number of questions reliability and validity are shown in Table 1.

The 'Questionnaire of Influence Teachers' Pro-industry Professionalization' was reviewed by three experts for subject contents' suitability to ensure the scale's expert validation. Four teachers were invited to answer the questionnaire to enhance the validity of the scale's contents. In addition, three tertiary schools were selected for a pre-test, and 109 teachers were selected as the pre-test objects in total. The scales used in this study are in self-assessment form, and a Likert 5-point scale is used as the scoring method. There are five levels of choices from 'agree' to 'do not agree;' five equal portions of 5 , 4, 3, 2 and 1 are distinguished according to the extent of agreement, and 5 points, 4 points, 3 points, 2 points and 1 point are given in this order. The higher the score an individual receives, the larger extent of agreement the individual has.

\section{Data analysis}

In processing the survey data used in this study, the collected questionnaires were coded, and Statistical Package for Social Science (SPSS) and linear structural analysis (LISREL) were used to verify the correlation among the factors of 'teaching self-efficacy,' 'industry experience' and 'pro-industry professionalization' variables and their effects in order to achieve the purpose of this study. In this study, the statistical test level $\alpha=0.05$.

TABLE I AN OVERVIEW OF FACTORS, NUMBER OF QUESTIONS, RELIABILITY AND VALIDITY OF INFLUENCE TEACHERS' PRO-INDUSTRY PROFESSIONALIZATION SCALE

\begin{tabular}{|c|c|c|c|c|c|c|c|c|c|c|c|}
\hline \multicolumn{4}{|c|}{ Teaching self-efficacy Scale } & \multicolumn{4}{|c|}{ Industry experience Scale } & \multicolumn{4}{|c|}{ Pro-industry professionalization Scale } \\
\hline Factor name & No. & $\begin{array}{c}\text { Cronba } \\
\operatorname{ch} \alpha\end{array}$ & $\begin{array}{l}\text { Factor } \\
\text { loading }\end{array}$ & Factor name & No. & $\begin{array}{c}\text { Cronba } \\
\operatorname{ch} \alpha\end{array}$ & $\begin{array}{l}\text { Factor } \\
\text { loading }\end{array}$ & Factor name & $\begin{array}{l}\mathrm{N} \\
\mathrm{o} .\end{array}$ & $\begin{array}{c}\text { Cronba } \\
\operatorname{ch} \alpha\end{array}$ & $\begin{array}{l}\text { Factor } \\
\text { loading }\end{array}$ \\
\hline $\begin{array}{c}\text { Teaching } \\
\text { motivation }\end{array}$ & 5 & .90 & $21.37 \%$ & $\begin{array}{l}\text { Industry } \\
\text { experience }\end{array}$ & 5 & .92 & $22.54 \%$ & $\begin{array}{l}\text { Outcome } \\
\text { value }\end{array}$ & 5 & .90 & $21.02 \%$ \\
\hline $\begin{array}{c}\text { Teaching } \\
\text { expectancy }\end{array}$ & 5 & .88 & $19.72 \%$ & $\begin{array}{l}\text { Industry } \\
\text { practice }\end{array}$ & 4 & .88 & $18.82 \%$ & $\begin{array}{l}\text { Outcome } \\
\text { self-efficacy }\end{array}$ & 5 & .89 & $20.13 \%$ \\
\hline $\begin{array}{l}\text { Teaching } \\
\text { outcome }\end{array}$ & 4 & .88 & $17.49 \%$ & $\begin{array}{l}\text { Industry } \\
\text { cognition }\end{array}$ & 4 & .86 & $17.23 \%$ & $\begin{array}{c}\text { Outcome } \\
\text { expectancy }\end{array}$ & 4 & .87 & $18.72 \%$ \\
\hline \multicolumn{2}{|c|}{$\begin{array}{l}\text { Total reliability } \\
\text { Cronbach } \alpha\end{array}$} & .87 & & \multicolumn{2}{|c|}{$\begin{array}{l}\text { Total reliability } \\
\text { Cronbach } \alpha\end{array}$} & .87 & & \multicolumn{2}{|c|}{$\begin{array}{c}\text { Total reliability } \\
\text { Cronbach } \alpha\end{array}$} & .98 & \\
\hline \multicolumn{2}{|c|}{$\begin{array}{c}\text { Accumulated } \\
\text { explained variance }\end{array}$} & & $58.58 \%$ & \multicolumn{2}{|c|}{$\begin{array}{c}\text { Accumulated } \\
\text { explained variance }\end{array}$} & & $58.59 \%$ & \multicolumn{2}{|c|}{$\begin{array}{c}\text { Accumulated explained } \\
\text { variance }\end{array}$} & & $59.97 \%$ \\
\hline
\end{tabular}

\section{RESULTS}

The empirical results of teachers' pro-industry professionalization are shown in Figure 1, and are analyzed as follows: The estimated value of the direct affecting parameter between teaching self-efficacy and industry experience is 0.59 $(\mathrm{t}=9.43, \mathrm{p}<.05)$. This means that teaching self-efficacy has a significant effect on 'industry experience'.

The estimated value of the direct affecting parameter between teaching self-efficacy and pro-industry 
professionalization is $0.38(\mathrm{t}=9.54, \mathrm{p}>.05)$. This means that teaching self-efficacy does not necessarily have a significant effect on pro-industry professionalization. The estimated value of the direct affecting parameter between industry experience and pro-industry professionalization is $0.73(\mathrm{t}=12.04, \mathrm{p}<.05)$. This means that industry experience has a significant effect on pro-industry professionalization. In summary, in this study of teachers' pro-industry professionalization and its influence pattern, teaching self-efficacy has a significant effect on industry experience, but does not have a significant effect on pro-industry professionalization. Industry experience has a significant effect on pro-industry professionalization.

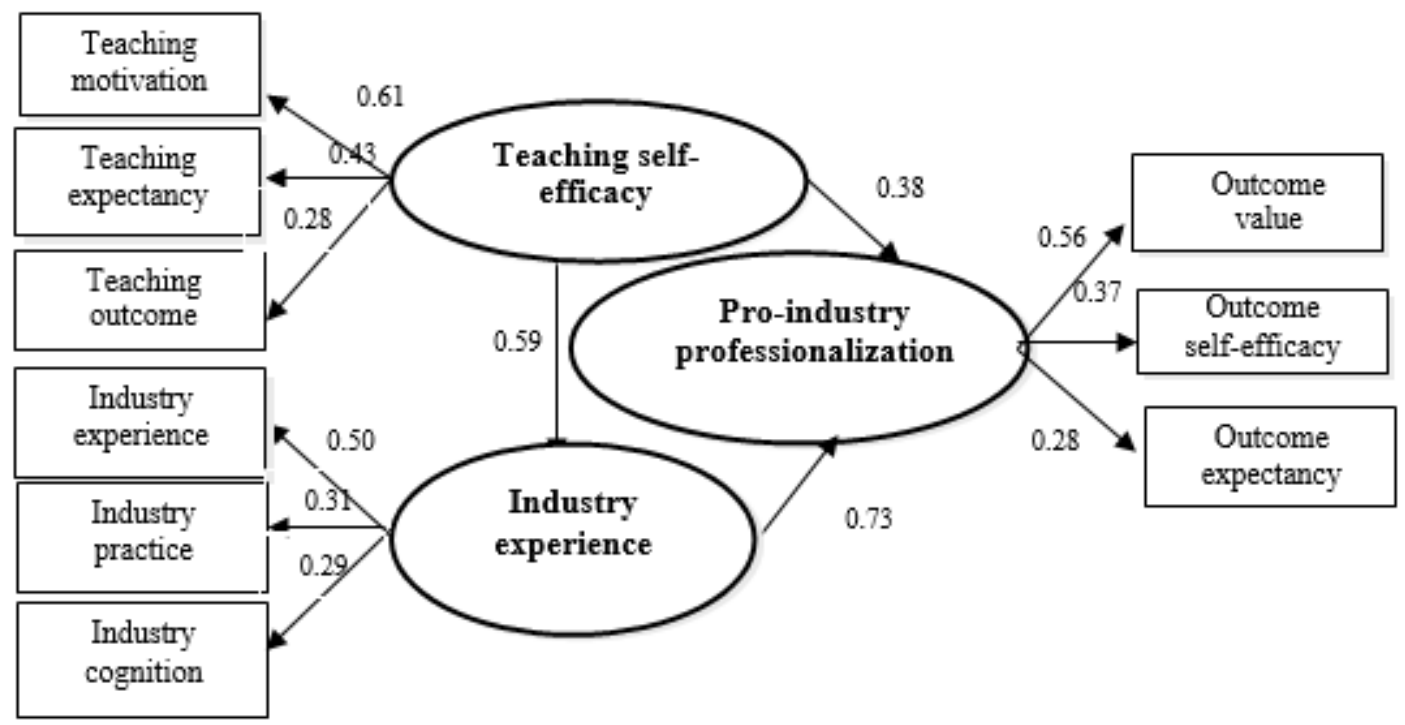

Fig. 1. Path of teachers' pro-industry professionalization

\section{CONCLUSION}

Teachers' industry experience has a significant direct effect on pro-industry professionalization, and teaching selfefficacy has a significant effect on pro-industry professionalization through industry experience. The influence pattern and empirical data of teaching self-efficacy and industry experience on pro-industry professionalization has a good fit. The influence effects of teaching self-efficacy, industry experience, and pro-industry professionalization show that for teachers, the influence of teaching self-efficacy on pro-industry professionalization comes mainly through their awareness of industry experience. In addition, industry experience has a direct and significant effect on pro-industry professionalization. From the influence of teaching selfefficacy, industry experience and pro-industry professionalization, we can clearly see that compared with teaching self-efficacy, industry experience has a greater influence on pro-industry professionalization [13].

Regarding the test results, according to the goodness of fit test standard by Hair et al, the model in this study has a good overall fit [14-15]. In the absolute fitness and incremental fitness tests, all indices meet the standard, and have the best fit. Most of the parsimonious fitness indices meet the test standard, and have a good fit. Overall, in the pro-industry professionalization and its influence model established in the study based on theories, both the model and the data have a good fit, and in the parameter estimation most of the estimated values are significant. This shows that all the indices of latent variables have their importance, and only the parameter value of teaching self-efficacy on pro-industry professionalization is low. Overall, the empirical data have a good explanatory power [16] [17]. Teachers' teaching self-efficacy influences industry experience and internship attitude is an important factor. Teachers' industry experience influences pro-industry professionalization, industry skills and Industry knowledge are important factors which influence pro-industry professionalization.

The results show that among all latent variables in the model, the direct influence of teaching self-efficacy on proindustry professionalization is not significant, indicating that the influence of teaching self-efficacy on teachers' proindustry professionalization needs further testing; this is something worthy of a more in-depth study and validation in the future. Based on test results, although the overall result is acceptable, the model consistency level is not entirely satisfactory, and its teaching self-efficacy has a relatively low explanatory power for pro-industry professionalization. The possible reasons are: The measurement error variance of the three main variables in the model is too large. Although in the course of the investigation in this study each step was made following reasonable procedures, in a sample survey there are a survey bias and restrictions on the study objects in answering the questionnaire. These can result in a bias between the survey data and the actual situation [12] [17].

The influence is test of indices and method. Currently in the verifying calculation of structural equations, the index value is subject to the sample size, and sometimes the index value may influence each other. When the index is far greater 
than or much lower than the standard value, the judgment is more accurate; when the index is close to the standard value, we then need to consider the possible influence from the error of the missing scope of variables. Although a complete research model was tried to be established in this study based on past researches and theories, there has been little domestic research on the topic of teachers' pro-industry professionalization.

\section{IMPLICATION}

There may be undetected factors which resulted in a low explanatory power, and there are other variables which have not been identified [11] [17]. Regarding this model's test results, perhaps in the future a further study can be conducted to find the variables either missing in the theories or can be further added or deleted, or more comprehensive empirical data can be collected for testing to improve the consistency between this model and empirical data.

\section{ACKNOWLEDGEMENT}

This paper was written while the authors were supported by a grant from the National Science Council, R.O.C. (MOST105-2511-S-224-001-MY3).

\section{REFERENCES}

[1] Bennett, S., Agostinho, S., and Lockyer, L. "Technology tools to support learning design: Implications derived from an investigation of university teachers' design practices.” Computers \& Education 81 (2015): 211-220.

[2] Kilday, J.E., Lenser, M.L., and Miller, A.D. "Considering students in teachers' self-efficacy: Examination of a scale for student-oriented teaching." Teaching and Teacher Education 56 (2016): 61-74.

[3] Locke, T., and Johnston, M. "Developing an individual and collective self-efficacy scale for the teaching of writing in high schools." Assessing Writng 28(2016): 1-14.
[4] S. Wang, J. Wan, D. Li, and C. Zhang. "Implementing Smart Factory of Industrie 4.0: An Outlook,"International Journal of Distributed Sen- sor Networks, in press(2016).

[5] Wang, S. Wan, J., Zhang, D., Li, D., and Zhang, C. "Towards smart factory for industry 4.0: a self-organized multi-agent system with big data based feedback and coordination." Computer Networks 101(4) (2016): 158-168.

[6] Lee, J., Bagheri, B., and Kao, H.A. "Research Letters A Cyber-Physical Systems architecture for Industry 4.0-based manufacturing systems “. Manufacturing Letters 3 (2015): 18-23.

[7] Faller, C., and Feldmüller, D. "Industry 4.0 Learning Factory for regional SMEs.” Procedia CIRP 32(2015): 88 - 91.

[8] Schuh, G., Gartzen, T., Rodenhauser, T. and Marks, A. "Pormoting work-based learning through Industry 4.0." Procediia CIRP 32 (2015): 82-87.

[9] Chesnut, S.R. and Burley, H. "Self-efficacy as a predictor of commitment to the tachign profession: A meta-analysis." Eduation Research Review 15 (2015): 1-16.

[10] Carter, A.G., Creedy, C.K., and Sidebotham, M. "Efficacy of teaching methods used to develop critical thinging in nursing and midwifery undergraduate students: A systematic review of the literature." Nurse Education Today 40(2016): 209-218.

[11] Hascher, T. and Hagenauer, G. "Openness to theory and its importance for pre-service teachers' self-efficacy, emotions, and classroom behqaviour in the teaching practicum." Internatinal Journall of Educational Research 77(2016): 15-25.

[12] Bentler, P.M. and Bonett, D.G. "Significance tests and goodness of fit in the analysis of covariance structures." Psychological Bulletin 88(3) (1980): 588-606.

[13] Hair, J.F. , Black, W.C., Babin, B.J. and Anderson, R.E. "Multivariate Data Analysis(7th ed.)," New Jersey: Pearson Prentice Hall (2010).

[14] Klassen, R.M. and Durksen, T.L. "Weekly, self-efficacy and work stress during the teaching practicum: A mixed methods study." Learning and Instruction 33 (2014):158-169.

[15] Klassen, R.M. and Tze, V.M.C. “Teachers' self-efficacy, personality and teaching effectiveness: A met-analysis." Educational Research Review 12 (2014): 59-76.

[16] Flores, I.M. "Developing preservice teachers' self-efficacy through field-based science teaching practice with elementary students." Research in Higher Education Journal 27 (2015):1-19.

[17] Chen, G. and Zhang, J. "Study on training system and continuous improving mechanism for mechanical engineering," The Open Mechanical Engineering Journal 9 (2015):7-14. 